OPEN ACCESS

Citation: Matthew Jo, Faluyi Jo (2021) Chromosomal analysis of eight cultivars in three species of cultivated Yam (Dioscorea L.) species in Nigeria. Caryologia 74(2): 3-9. doi: 10.36253/caryologia-840

Received: January 02, 2020

Accepted: April 26, 2021

Published: October 08, 2021

Copyright: @2021 Matthew Jo, Faluyi Jo. This is an open access, peer-reviewed article published by Firenze University Press (http://www.fupress.com/caryologia) and distributed under the terms of the Creative Commons Attribution License, which permits unrestricted use, distribution, and reproduction in any medium, provided the original author and source are credited.

Data Availability Statement: All relevant data are within the paper and its Supporting Information files.

Competing Interests: The Author(s) declare(s) no conflict of interest.

ORCID

MJ: 0000-0003-3401-9327

\section{Chromosomal analysis of eight cultivars in three species of cultivated Yam (Dioscorea L.) species in Nigeria}

\author{
Joshua Matthew ${ }^{1,2, \star}$, Julius Oloaye Faluyi ${ }^{1}$ \\ ${ }^{1}$ Botany Department, Obafemi Awolowo University, Ile-Ife, Nigeria \\ ${ }^{2}$ National Horticultural Research Institute, Ibadan, Nigeria \\ *Corresponding author, jolumatthew@gmail.com
}

\begin{abstract}
The genus Dioscorea comprises of economically-important plant species known for their starch throughout the world; it is also a major source of food and income in Africa. The most important Dioscorea species cultivated and consumed in the West Africa belt include D. cayenensis, D. rotundata and D. alata. The plant materials used in this study were collected from Omu-Ekiti, Oye Local Government of Ekiti State, Nigeria using the On Farm Participatory Method (OFPM). Mitotic chromosome studies were carried out on three species viz, Dioscorea alata ('ewura'), D. cayenensis ('igangan') and D. rotundata ('areyingbakumo', 'gaungaun', 'ikumo', 'ogunmole' and 'sandpaper'). Mitotic chromosome studies were carried out on each of the cultivars using the root tip squash method made in modified Orcein stain (FLP-Orcein). Dormant tubers were cut to mini-setts and placed in carbonised rice husk for rooting. This study reports the basic chromosome number of $\mathrm{x}=8$, i.e. $2 \mathrm{n}=4 \mathrm{x}=32$ (D. alata), $2 \mathrm{n}=$ $4 \mathrm{x}=38$ (D. rotundata) and $2 \mathrm{n}=8 \mathrm{x}=68$ (D. cayenensis) for Dioscorea suggesting that both $D$. rotundata and $D$. cayenensis are aneuploids.
\end{abstract}

Keywords: Dioscorea, Chromosomes, aneuploids, polyploids, mixoploidy.

\section{INTRODUCTION}

The genus Dioscorea L. belongs to the family Dioscoreaceae which includes about $90 \%$ of the species in the family (Murti 2001). The genus Dioscorea is principally tuber-bearing and has great economic value in the tropics as food, pharmaceutical, starch, socio-cultural uses and source of income to farmers in West and Central Africa (Asiedu et al. 1998; Séka et al. 2009). The most important Dioscorea species cultivated and consumed in the West Africa belt include D. cayenensis Lam., D. rotundata Poir. and D. alata L. (IITA 2009). West African countries produce over $90 \%$ of world Dioscorea, of which, Nigeria is the largest producer of Dioscorea in the world, producing over $60 \%$ of the world Dioscorea (FAO 2016; 2017).

Dioscorea has presented a challenge to systematists for many years due to its great morphological diversity, its reproductive biology: dioecy, small flowers, low or no seed set and tuber propagation (Wilkin et al. 2005). Nor- 
man et al. (2012) has reported the difficulty of chromosome studies in yams (Dioscorea spp.) due to the small dot-like chromosomes and few dividing cells in the root tips. Also, mixoploidy has been reported to be characteristic of many highly productive commercial cultivars with small chromosome sizes (Kunakh 2005; Kunakh et al. 2008). Mixoploidy was reported by Baquar (1980) in some Dioscorea species studied which he tagged "odd chromosome numbers"

Dioscorea alata was reported to have the highest diversity in polyploidy ranging between $2 n=30$ and $2 n$ $=80$ (Sharma and Deepesh 1956; Franklin and Oritz 1963; Egesi et al. 2012). The ploidy levels of D. cayenensis have been reported to range between a tetraploid ( $2 \mathrm{n}$ $=4 \mathrm{x}=40)$ and an octoploid $(2 \mathrm{n}=8 \mathrm{x}=80)$ on a basic chromosome number of 10 (Baquer 1980; Gamiette et al. 1999; Dansi et al. 2001). A basic chromosome number of 20 has been suggested using D. cayenensis (Dora et al. 2005) and D. alata (Arnau et al. 2009).

Flow cytometry has offered some advantages in ploidy level analysis (Babil et al. 2010). Two ploidy levels $(4 \mathrm{x}$ and $8 \mathrm{x}$ ) were detected by flow cytometry in two populations of $D$. cayenensis and $D$. rotundata cultivars (Dansi et al. 2000; Babil et al., 2010). However, this technique has failed to detect aneuploidy in this population. Therefore, Babil et al. (2010) recommended the use of classical chromosome studies to determine ploidy levels and solve the complication of mixoploidy in the genus Dioscorea. Babil et al. (2010) then recommended that determination of the basic chromosome number of Dioscorea spp. requires further investigations. Norman et al. (2012) advocated the need for chromosome studies which is necessary to clarify the structure, function, organisation and evolution of yam genomes.

The aim of this study was to investigate the chromosome number of the cultivars in the three major Dioscorea species that are present in Nigeria using the squash technique. The results presented will be useful both in the identification and understanding of the phylogenetic relationship among the major cultivars in the three major species of Dioscorea.

\section{METHODOLOGY}

The plant materials used in this study were collected from Omu-Ekiti (N 07.90497’ E 005.39092') in the Oye Local Government of Ekiti State, Nigeria. This community typifies an epicentre of loss of genetic resources as a result of mass adoption of introduced Dioscorea cultivars by migrant farmers from the Middle Belt of Nigeria in the last twelve years. Mitotic chromosome studies were carried out on seven cultivars in three species: Dioscorea alata, D. cayenensis and $D$. rotundata. Dormant tubers were cut into mini-setts placed in carbonised rice husk for rooting. The root tips were harvested between 10.30$11.30 \mathrm{am}$, rinsed in water and transferred into 1:3 Acetic Ethanol fixative. This was left on the working bench for $24 \mathrm{~h}$ at room temperature before keeping in the refrigerator for future usage. The root tips for examination were hydrolysed in $18 \% \mathrm{HCl}$ for $10 \mathrm{~min}$, squashed and stained with FLP-Orcein. Photomicrographs of the good mitotic chromosome spreads were documented under oil immersion (x1000) objective magnification using BK Series Phase Contrast Microscope (PW-BK 5000T) equipped with a DCM510 5 Megapixel camera. The chromosome numbers were based on five consistent counts.

\section{RESULTS}

\section{Phenotypic variation in leaf characters}

Table 1 and Figure 1 show the forms and shapes of the leaves of some of the Dioscorea species studied. All the cultivars studied had simple, glabrous, cordate leaves. The petiole of $D$. alata ('ewura') had purple wing which was absent in other species. The leaves of $D$. rotundata ('areyingbakumo') and D. cayenensis ('igangan') cultivars had orbiculate (broad cordate) leaves.

Table 1. Leaf characteristics of the Yam cultivars studied.

\begin{tabular}{|c|c|c|}
\hline Species & Local name & Foliar description \\
\hline Dioscorea alata & Ewura & $\begin{array}{l}\text { Green colour, ovate shape, } \\
\text { acuminate apex, cordate base } \\
\text { and winged petiole. }\end{array}$ \\
\hline Dioscorea cayenensis & Igangan & $\begin{array}{l}\text { Light green colour, orbicular } \\
\text { shape, acuminate apex and } \\
\text { cordate base. }\end{array}$ \\
\hline \multirow[t]{5}{*}{ Dioscorea rotundata } & Areyingbakumo & $\begin{array}{l}\text { Green colour, orbicular } \\
\text { shape, acuminate apex and } \\
\text { cordate base. }\end{array}$ \\
\hline & Gaungaun & $\begin{array}{l}\text { Green colour, ovate shape, } \\
\text { acuminate apex and sagittate } \\
\text { base. }\end{array}$ \\
\hline & Ikumo & $\begin{array}{l}\text { Green colour, orbicular } \\
\text { shape, acuminate apex and } \\
\text { cordate base. }\end{array}$ \\
\hline & Ogunmole & $\begin{array}{l}\text { Green colour, ovate shape, } \\
\text { acuminate apex and cordate } \\
\text { base. }\end{array}$ \\
\hline & Sandpaper & $\begin{array}{l}\text { Dark green colour, long } \\
\text { ovate shape, acuminate apex } \\
\text { and sagittate base. }\end{array}$ \\
\hline
\end{tabular}



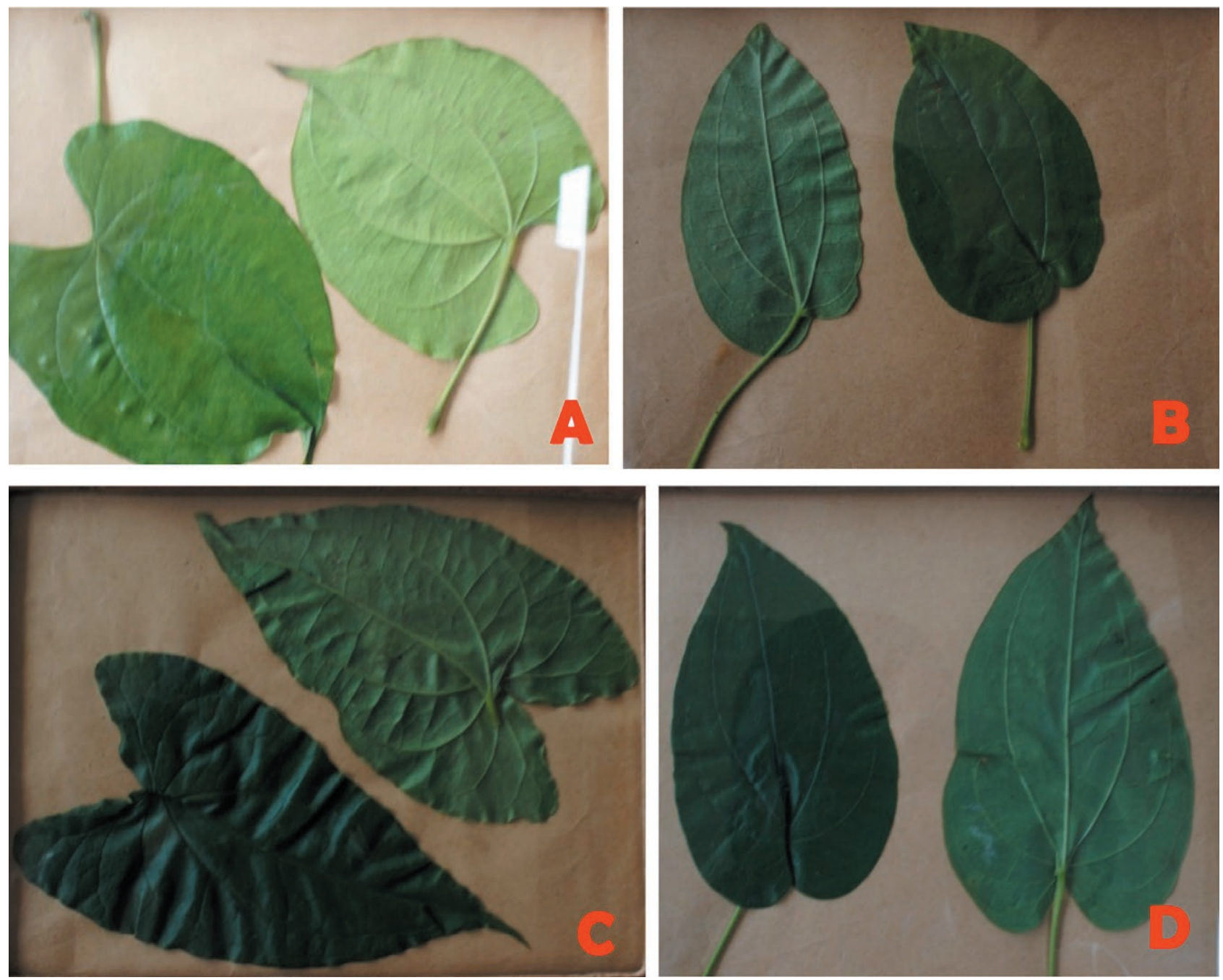

Figure 1. Leaf form and shape in some the cultivars of Dioscorea studied. (a) D. cayenensis (b) D. rotundata (c) D. rotundata (d) D. rotundata

However, the leaf colour of $D$. cayenensis was light green while that of $D$. rotundata were dark green. Only, $D$. rotundata ('sandpaper') had long cordate leaves. The cultivars had acuminate leaf apices. The leaf bases observed in D. rotundata, ('gaungaun' and 'sandpaper' cultivars) were sagittate while other $D$. rotundata cultivars studied had cordate leaf bases.

\section{Chromosome number and morphology}

The mitotic chromosome counts observed in the Dioscorea species studied were shown in Figures 2 and 3. A mitotic chromosome count of $2 \mathrm{n}=32$ was observed in $D$. alata cultivar while a mitotic chromosome count of $2 \mathrm{n}=68$ was observed in the $D$. cayenensis cultivar
(Figure 2). The mitotic chromosome count observed in all the $D$. rotundata cultivars was $2 \mathrm{n}=38$ (Figures 2 and 3). Table 2 shows the mitotic chromosome counts in this study and the previous chromosome counts. The morphology of the chromosomes could not be ascertained in this study because of their small sizes.

\section{DISCUSSION}

The findings of this study revealed morphological variations between and within the leaves of the cultivars of the Dioscorea species studied. As established in Table 1 and Figure 1, the distinct by its winged petiole of $D$. alata distinguishes it from delimit the $D$. rotundata and D. cayenensis cultivars while can be. Also, leaf colour 

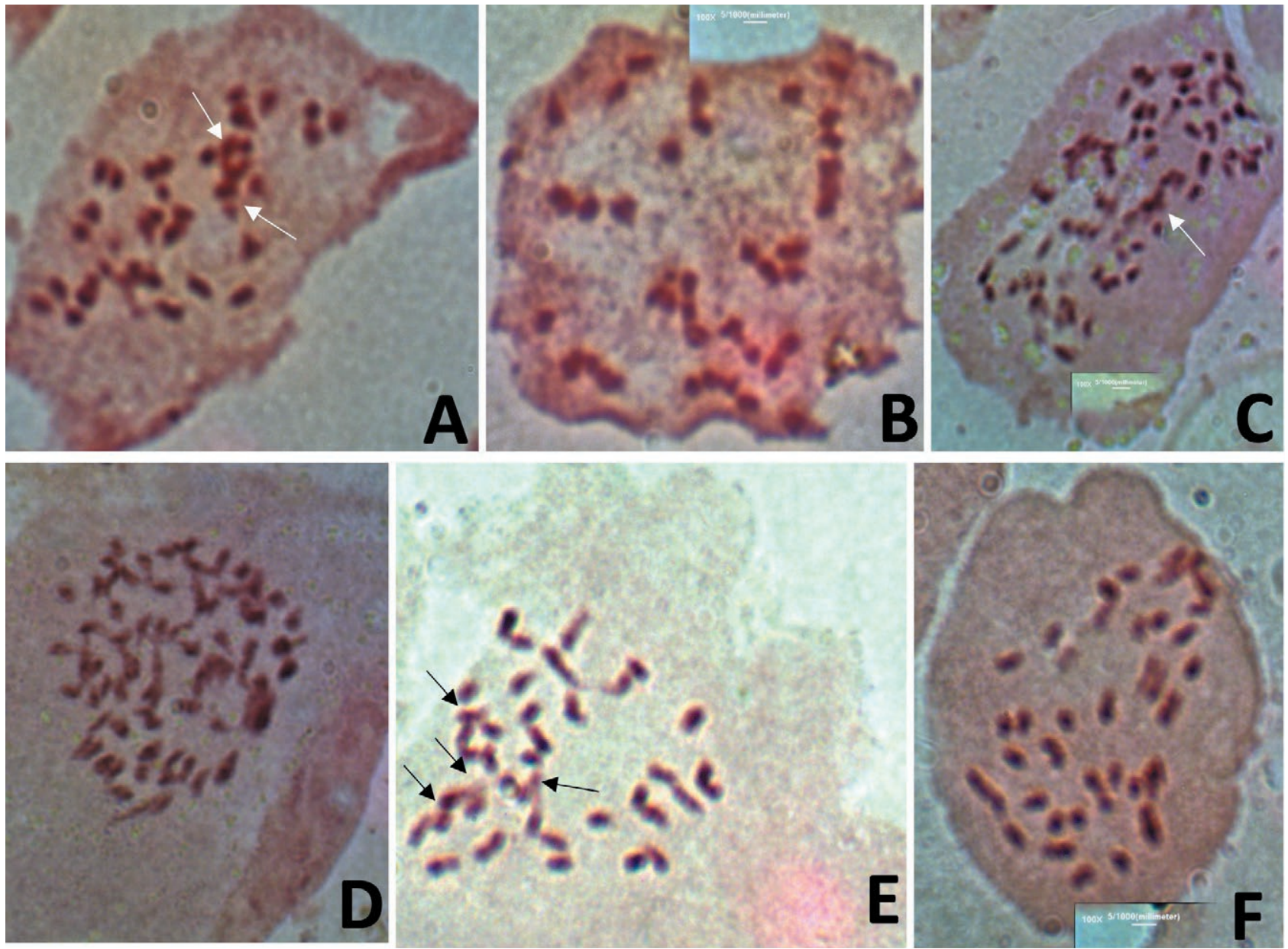

Figure 2. Mitotic metaphase spreads in the Dioscorea species studied. A. D. alata (Ewura), $2 \mathrm{n}=32$ (Arrows show mitotic chromosome overlaps); B. D. alata (Ewura), $2 \mathrm{n}=32$; C. D. cayenensis (Igangan), $2 \mathrm{n}=68$ (Arrow shows mitotic chromosome overlap); D. D. cayenensis (Igangan), $2 \mathrm{n}=68$; E. D. rotundata (Ikumo), $2 \mathrm{n}=38$ (Arrows show mitotic chromosome overlap); F. D. rotundata $($ Ikumo), $2 \mathrm{n}=38$.

serves as a delimiting character, D. cayenensis has lightgreen leaves while $D$. rotundata has dark-green leaves and $D$. alata leaves are green. The orbicular leaf shape of $D$. cayenensis distinguish it from some $D$. rotundata and D. alata cultivars. However, in the morphological characterisation of Dioscorea, there is possibility of overlap of characters, therefore, the use of multiple delimiting features is important for their characterisation.

This study established a chromosome number of $2 n$ $=38$ for the four cultivars of Dioscorea rotundata, $2 \mathrm{n}$ $=32$ for $D$. alata and $2 \mathrm{n}=68$ for $D$. cayenensis. None of the mitotic counts observed in this study is in agreement with the previous mitotic chromosome numbers reported for yam (Table 1). (Bousalem et al. 2006) reported that the dot-like and varying chromosome sizes that occurred in the mitotic cells of Dioscorea made the definite determination of chromosome numbers difficult. The mitotic chromosome counts reported in this study were smaller compared to the mitotic chromosome numbers earlier reported. Asiedu et al. (1998) had reported the occurrence of smaller chromosome numbers and polyploidy levels in the species of Dioscorea from Asia and Africa.

This study reports the basic chromosome number of $\mathrm{x}=8$ in $D$. alata $(2 \mathrm{n}=4 \mathrm{x}=32), D$. rotundata, $(2 \mathrm{n}=4 \mathrm{x}$ $=38)$ and $D$. cayenensis $(2 \mathrm{n}=8 \mathrm{x}=68)$. The $\mathrm{x}=8$ basic chromosome number agrees with the findings of (Dansi et al. 2001). There was no mixoploidy observed. Baquar (1980) reported odd chromosome numbers that were not direct multiples of their basic chromosome numbers which he tagged "odd chromosome numbers". The study cytogenetics of Dioscorea using roots from tubers could give a better result in terms chromosome morphology and stainability compared to vines generated roots.

The findings indicate that $D$. rotundata $(2 \mathrm{n}=38)$ and $D$. cayenensis $(2 n=68)$ are distinct species. This 

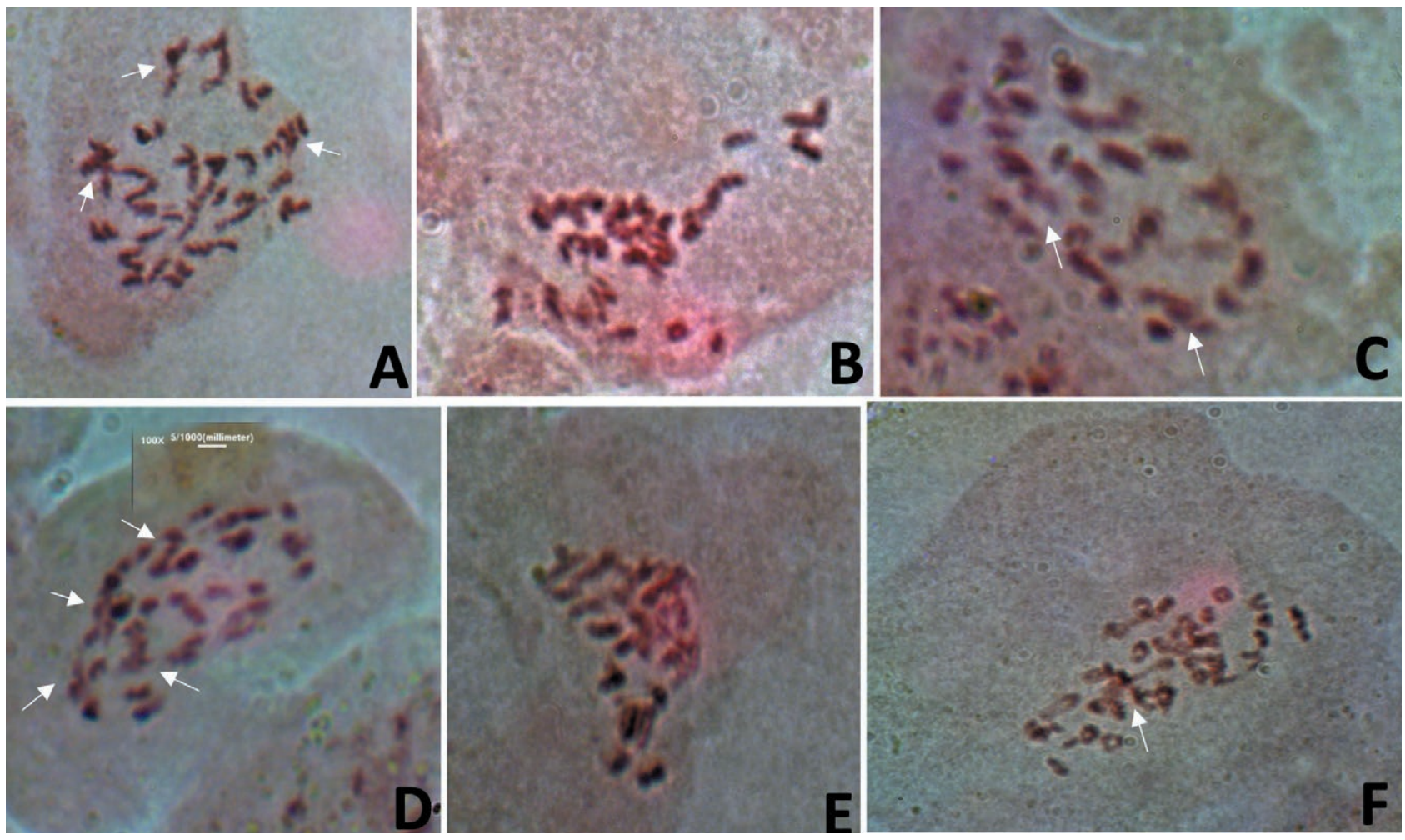

Figure 3. Mitotic metaphase spread in Dioscorea species studied. A. D. rotundata (Gaungaun), $2 \mathrm{n}=38$ (Arrows show chromosome overlaps); B. D. rotundata (Gaungaun), $2 \mathrm{n}=38$; C. D. rotundata (Sandpaper), $2 \mathrm{n}=38$ (Arrows show chromosome overlaps); D. D. rotundata (Ogunmole), $2 \mathrm{n}=38$ (Arrows show chromosome overlaps); E. D. rotundata (Areyingbakumo), $2 \mathrm{n}=38 ;$ D. rotundata (Areyingbakumo), $2 \mathrm{n}$ $=38$ (Arrow shows chromosome overlap)

study affirms that $D$. cayenensis is a distinct species from D. rotundata thus corroborating the results of Bressan et al. (2014) who classified the two species separately through isozymatic analysis. D. cayenensis might be a speciated polyploid of $D$. rotundata based on the leaf morphology and the chromosome count reported in this study. Dioscorea is principally propagated vegetatively, hence, $D$. cayenensis could have arose through the process somatic cell divisions and polyploidy. The probability that this occurrence could have been as a result of abnormality in the somatic cell divisions of the planting materials (Sharma and Deepesh 1956; Stebbins 1971; Baquar 1980) is considered remote.

Polyploidy has been reported in domesticated plants which include Dioscorea species (Lewis 1980; Leitch and Leitch 2008; Jeredi et al. 2012). Based on a basic number of $\mathrm{x}=8$ (Dansi et al., 2001), D. alata $(2 \mathrm{n}=4 \mathrm{x}=32)$ is a tetraploid and $D$. rotundata $(2 \mathrm{n}=38)$ can only be an aneuploid trisomic for six linkage groups while $D$. cayenensis $(2 \mathrm{n}=68)$ would be an octaploid with four trisomic sets.

\section{CONCLUSION}

The chromosome numbers reported in this work are based on five consistent counts for all the cultivars. It is difficult to agree that mixoploidy is an issue in the chromosome numbers of the cultivars studied because the analysable cells did not show wide variations in chromosome number. On the other hand, for a crop that is maintained by clonal propagation, the occurrence of multiple chromosome numbers is not impossible, especially since a cultivar is not a taxonomic hierarchy. Rather, it is characterized by a cluster of valuable food and agronomic attributes that have distinguished it for selection and conservation through generations of cultivation by peasant farmers.

\section{ACKNOWLEDGEMENTS}

The authors are grateful to Dr S.O. Azeez (Botany Dept. OAU) and Mr O.F. Oyelami (IITA, Ibadan) for the information and suggestions provided in the course of this study. 
Table 2. Present and previous reports of chromosome numbers in the genus Dioscorea.

\begin{tabular}{|c|c|c|c|}
\hline Species & Present & Previous & Reference \\
\hline \multirow[t]{8}{*}{ D. alata } & \multirow[t]{8}{*}{32} & 20 & Sharma and Sharma (1957) \\
\hline & & 30 & $\begin{array}{l}\text { Sharma and Deepesh } \\
\text { (1956)56 }\end{array}$ \\
\hline & & 40 & $\begin{array}{l}\text { Miége (1954); Simmond } \\
\text { (1954); Sharma and Deepesh } \\
\text { (1956), Raghavan (1958), } \\
\text { Martin and Ortiz (1963); } \\
\text { Ramachandran } \\
\text { (1962; 1968); Baquar (1980) }\end{array}$ \\
\hline & & 50 & $\begin{array}{l}\text { Sharma and De (1956); } \\
\text { Baquar (1980) }\end{array}$ \\
\hline & & 60 & $\begin{array}{l}\text { Raghavan (1948); Martin and } \\
\text { Ortiz (1963); Ramachandran } \\
(1962 ; 1968) .\end{array}$ \\
\hline & & 70 & Sharma and De (1956) \\
\hline & & 80 & $\begin{array}{l}\text { Raghavan (1948); } \\
\text { Ramachandran (1962; 1968); } \\
\text { Baquar (1980) }\end{array}$ \\
\hline & & $81 \pm$ & Nakajima (1936). \\
\hline \multirow[t]{6}{*}{ D. cayenensis } & \multirow[t]{6}{*}{68} & 34 & Miége (1954). \\
\hline & & 36 & Miége (1954). \\
\hline & & 54 & Miége (1954). \\
\hline & & $60,62,63,66 \pm$ & Miége (1954); Baquar (1980) \\
\hline & & 80 & Baquar (1980) \\
\hline & & 140 & Smith, 1937 \\
\hline \multirow[t]{2}{*}{ D. rotundata } & \multirow[t]{2}{*}{38} & 40 & $\begin{array}{l}\text { Martin and Ortiz (1963); } \\
\text { Baquar (1980) }\end{array}$ \\
\hline & & 60 & Baquar (1980) \\
\hline
\end{tabular}

\section{REFERENCES}

Abraham, K., Nair, P. G., 1991. Polyploidy and sterility in relation to sex in Dioscorea alata L. (Dioscoreaceae). Genetica 83: 93-97.

Arnau, G., Nemorin, A., Maledon, E., Abraham, K., 2009. Revision of ploidy status of Dioscorea alata L. (Dioscoreaceae) by cytogenetic and microsatellite segregation analysis. Theor Appl Genet. 118: 1239-1249.

Asiedu, R., Ng, S., Bai, K., Ekanayake, I., Wanyera, N., 1998. Genetic Improvement. In: Food Yams, Adv. Res. 63-104.

Ayensu, E. S., 1972. Anatomy of the Monocotyledons. Clarendon Press, Oxford, pp. 182.

Babil, P.K., H. Kikuno, H. Shiwachi, H. Toyohara, J. Fujigaki, H. Fujimaki and R. Asiedu., 2010. Optimum time for collection of root samples for chromosome observation in yams (Dioscorea Spp.). Trop. Agr. Develop. 54(3): 71-75.

Baquar, S. R., 1980. Chromosome behaviour in Nigerian yams (Dioscorea). Genetica, 54(1): 1-9.
Bousalem, M., Arnau, G., Hochu, I., Arnolin, R., Viader, V., Santoni, S., David, J., 2006. Microsatellite segregation analysis and cytogenetic evidence for tetrasomic inheritance in the American yam Dioscorea trifida and a new basic chromosome number in the Dioscoreae. Theor Appl Genet 113: 439-451.

Bressan, E.A., Neto, T.B., Zucchi, M.I., Rabello, R.J., Veasey, E.A., 2014. Genetic structure and diversity in the Dioscorea cayenensis/D. rotundata Complex revealed by morphological and Isozyme Markers. Genetics and Molecular Research 13(1): 425-37.

Dansi, A., Mignouna, H.D., Zoundjihékpon, J., Sangare, A., Ahoussou, A., Asiedu, R., 2000. Identification of some Benin Republic's Guinea yam (Dioscorea cayenensis/Dioscorea rotundata complex) accessions using Randomly Amplified Polymorphic DNA. Genetic Resources and Crop Evolution 47: 619-625.

Dansi, A., Pillay, M., Mignouna, H.D., Mondeil, F., Dainou, O., 2001. Ploidy level of the cultivated yams (Dioscorea cayanensis-Dioscorea rotundata complex) from Benin Republic determined by chromosome counting and flow cytometry. Afr. Crop Sci. J. 8: 355364.

Egesi, C. N., M. Pillay, R. Asiedu, J. K. Egunjobi., 2002. Ploidy analysis in water yam, Dioscorea alata $\mathrm{L}$. germplasm. Euphytica 128: 225-230.

Faluyi, J.O., Olorode, O., 1988. Mitotic chromosomes studies in nymphal and adult populations of Zonocerus variegatus L. (Orthoptera: Pyrgomorphidae). J. Afri. Zool. 102: 475-480.

FAO, 2016. FAOSTAT Database. Food and Agriculture Organization, Rome, Italy.

FAO, 2017. FAOSTAT Database. Food and Agriculture Organization, Rome, Italy.

Franklin, W. M., Ortiz, S., 1963. Chromosome numbers and behaviour in some species of Dioscorea. Cytologia 28: 97-101.

Gamiette, F. Bakry, F., Ano, G.,1999. Ploidy determination of some yam species (Dioscorea spp.) by flow cytometry and conventional chromosome counting. Genet. Resour. Crop Evol. 46: 19-27.

IITA, 2009. Yam. International Institute of Tropical Agriculture, Ibadan, Nigeria.

Jeridi, M., Perrier, X., Rodier-Goud, M., Ferchichi, A., D’Hont1, A., Frédéric B., 2012. Cytogenetic evidence of mixed disomic and polysomic inheritance in an allotetraploid (AABB) Musa genotype. Annals of Botany 110: 1593-1606.

Kunakh, V. A., Adonin, V. I., Ozheredov, S. P., Blyum., Y. B., 2008. Mixoploidy in Wild and Cultivated species of cruciferae capable of hybridizing with rapeseed Brassica napus. Cytology and Genetics, 42(3): 204-209. 
Kunakh, V.A., 2005. Biotekhnologiya likars'kykh roslyn. Genetychni ta fiziologo- biokhimichni osnovy (Biotechnology of Medicinal Plants. Genetic and Physiological and Biochemical Aspects), Kiev: Logos.

Leitch, A.R., Leitch, I.J., 2008. Genomic plasticity and the diversity of polyploid plants. Science 320: 481-483.

Lewis, W.H., 1980. Polyploidy: biological relevance. Plenum Press, New York pp. 45-60.

Marie F. S., Ngo-Ngwe, S. J., Mickaël B., Spencer B., Denis N. O., 2014. Nuclear DNA Content Analysis of Four Cultivated Species of Yams (Dioscorea). J. Plant Breed. Genet. 2(2): 87-95.

Martin, F. W., Delfel, N. E., Cruzado, H. J., 1963. Dioscorea friedrichsthalii, another sapogenin bearing species. Turrialba 13: 159-163.

Martin, F.W., Ortiz, S., 1963. Chromosome number and behaviour in some species of Dioscorea. Cytologia 28: 96-101.

Matthew, J.O., Oziegbe, M., 2016. Intraspecific and Interspecific of Four Ocimum Species. Nigeria Journal of Genetics 30: 8-12.

Miège, J., 1954. Chromosome number and geographical distribution of some tropical and equatorial plants. Journal of Cytogenetics and Plant Biology 15: 312348.

Murti, S. K., 2001. Flora of Cold Deserts of Western Himalaya. Vol. 1. (Monocotyledons).

Mustapha, B., Arnau, G., Hochu, I., Arnolin, R., Viader, V., Santoni, S., David, J., 2006. Microsatellite segregation analysis and cytogenetic evidence for tetrasomic inheritance in the American yam Dioscorea trifida and a new basic chromosome number in the Dioscorea. Theoretical and Applied Genetics 113: 439-451.

Muthamia, Z.K., Nyende, A.B., Mamati, E.G., Ferguson, M.E., Wasilwa., J., 2014. Determination of ploidy among Yam (Dioscorea spp.) landraces in Kenya by flow cytometry. Afr. J. Biotechnol. 13(3): 394-402.

Nora, S., Dainou, O., Agbangla, C., Tostain, S., Pham, J. L., 2005. Segregation patterns of isozyme loci and microsatellite markers show the diploidy of African yam Dioscorea rotundata $(2 \mathrm{n}=40)$. Theoretical Applied Genetics 111: 226-232.

Norman, P.E., Tongoona, P., Shanahan, P. E., 2012. "Diversity in Chromosome Number and Raphide Morphology of Yam (Dioscorea Spp) Genotypes from Sierra Leone. African Journal of Plant Science 6(4): 157-162.

Nweke, F.I., Ugwu, B.O., Asadu, C.L.A., Ay, P., 1991. Production costs in the yam- based cropping systems of southwestern Nigeria. Research Monograph No. 6, IITA, Ibadan, Nigeria. Resource and Crop Management Division. p. 29.
Obidiegwu, J., J. Loureiro, E. Ene-Obong, E. Rodriguez, M. Kolesnikova-Allen, C. Santos, C. Muoneke and R. Asiedu, 2009. Ploidy level studies on the Dioscorea cayenensis/Dioscorea rotundata complex core set. Euphytica 169(3): 319-26.

Olorode O., Barquer, S.R., 1976. The Hyparrhenea involucrate - H. subplumosa Gramineae complex in Nigeria. Morphological and cytological charactization. Botanical Journal of Linnean Society, 72: 212-222.

Pal, A., Sharma, A. R., 1980. Analysis of cytotypes of Dioscorea and scope of increasing the diosgenin content. Cellule 73: 117-134.

Raghavan, R.S., 1958. A chromosome survey of Indian Dioscorea. Proc. Indian Acad. Sci, 48: 59-63.

Ramachandran, K., 1962. Studies on the cytology and sex determination of the Dioscoreaceae. J. Indian Bot. Soc. 41: 93-98.

Ramachandran, K., 1968. Cytological studies in Dioscorea. Cytologia 33: 401-410.

Scarcelli, N. Daïnou, O., Agbangla, C., Tostain, S., Pham. J.L., 2005. Segregation patterns of isozyme loci and microsatellite markers show the diploidy of African Yam Dioscorea Rotundata $(2 \mathrm{n}=40)$. Theoretical and Applied Genetics 111(2): 226-232.

Séka, K., Diallo, A., Kouassi, K., Aké, S., 2009. Incidence of Yam Mosaic Virus (YMV) and Cumcuber Mosaic Virus (CMV) on varieties of Dioscorea spp. cultivated in the Bouake and Toumodi regions of Côte d'Ivoire. Inter. J. Biologic. Chemic. Sci. 3: 694-703.

Sharma, A. K., Deepesh, D.E., 1956. Gallic acid--its importance in cytochemical studies. Caryologia 6(23): $180-189$.

Sharma, A.K., Sharma, A., 1957. Investigation leading to a new theory of differentiation in plant cells. Genet. iber. 9: 143-162.

Simmonds, N.W., 1954. Chromosome behaviour in some tropical plants. Heredity 8: 139-146.

Smith, B. W., 1937. Notes on the cytology and distribution of the Dioscoreaceae. Bulletin of the Torrey Botanical Club. Torrey Botanical Society. 64(4): 189197.

Stebbins, G. L., 1971. Processes of organic evolution, pp. 103-105.

Sun, X., Xue, J., Lei, Z., Li, M., Zhang, Y., Zhou, G., Hang, Y., 2018. Taxonomic and phylogenetic significance of leaf venation characteristics in Dioscorea plants. Archives of Biological Sciences 70(2): 397-407.

Wilkin, P., Scholes, P., Mark, W.C., Kongkanda, C., Carol, A.F., Suzy, H., Franck, R., Erik, S., Chirdsak, T., 2005. A plastid gene phylogeny of the yam genus, Dioscorea: roots, fruits and Madagascar. Syst. Bot. 30(4): 736-749. 